\title{
A Tale of Two Urchins - Implications for In-Situ Breeding of the Endangered Banggai Cardinalfish (Pterapogon kauderni)
}

\author{
Samliok Ndobe ${ }^{1 *}$, Jamaluddin Jompa $^{2}$ and Abigail Moore ${ }^{3}$ \\ ${ }^{1}$ Aquaculture Study Program, Tadulako University, Palu, Indonesia \\ ${ }^{2}$ Faculty of Marine Science and Fisheries, Hasanuddin University, Makassar, Indonesia \\ ${ }^{3}$ PhD Program in Fisheries Science, Faculty of Marine Science and Fisheries, Hasanuddin University, Makassar, Indonesia \\ ${ }^{*}$ Corresponding author: samndobe@yahoo.co.id
}

Received: 11 December 2017; Accepted: 23 July 2018

\begin{abstract}
Samliok Ndobe, Jamaluddin Jompa and Abigail Moore. 2018. A Tale of Two Urchins - Implications for In-Situ Breeding of the Endangered Banggai Cardinalfish (Pterapogon kauderni). Aquacultura Indonesiana, 19 (2): 65-75. The endangered Banggai cardinalfish Pterapogon kauderni, endemic to the Banggai Archipelago in Central Sulawesi, Indonesia, is a national and global priority conservation species. To support stock recovery based on in-situ breeding, using the symbiosis between the Banggai cardinalfish and its microhabitat (especially urchins of Genus Diadema), specific research objectives were: (i) identify the Diadema species associated with Banggai cardinalfish in the wild; (ii) investigate Banggai cardinalfish preference between these Diadema species. Belt transect data (5 sites) found wild Banggai cardinalfish of all size classes associated with Diadema setosum and Diadema savignyi. Preference trials were conducted in a controlled environment (concrete tanks) with three replicates. Nine sub-adult Banggai cardinalfish (35-42 mm SL), 12 D. setosum and 12 D. savignyi were placed in each tank. Banggai cardinalfish association (D. savignyi, D. setosum, none) was recorded hourly (06:00-18:00) for three days and results analysed in RStudio-1.0.143. Banggai cardinalfish did not show significant preference for either $D$. savignyi or D. setosum. These results indicate that $D$. savignyi and D. setosum can be used impartially in further research on in-situ breeding to facilitate recovery of Banggai cardinalfish stocks. However stock recovery measures should consider genetic connectivity and the natural balance between the two urchin species.
\end{abstract}

Keywords: Banggai cardinalfish; Diadema; In-situ breeding; Microhabitat preference; Stock recovery; Symbiosis

\section{Introduction}

There is no longer any reasonable doubt that humanity is radically changing the biosphere in which we all live, to the extent that many scientists believe we are now in a new geological era, the Anthropocene or Age of Mankind (Crutzen, 2002: Steffen et al., 2011; Zalasiewicz et al., 2011; Barnosky, 2014), an age where "humans are becoming the dominant force of change on earth" (Schwägerl, 2014). As a species, we are altering the chemical composition of both our atmosphere and oceans, bringing changes in climate and threats to ecosystem integrity, including key marine and coastal ecosystems (Ellis, 2011; IPCC, 2014; Hoegh-Guldberg et al., 2017). In particular, there is strong scientific consensus that anthropogenic activities are responsible for a growing number of species extinctions, to the point where many consider that we are both causing and witnessing the $6^{\text {th }}$ major extinction event in the history of life on earth (Dirzo et al., 2014), especially life in the seas (Jackson, 2008). Major shifts in marine fauna species ranges and community composition have begun, and especially high extirpation (local/regional extinction) rates are predicted in the Indo-Pacific (Cheung et al., 2009; Jones and Cheung, 2014; Molinos et al., 2016).

Initiatives at all levels (genetic, species, ecosystem, ecoregion, etc.) based on sound science are vital to reduce the rate of biodiversity loss and the negative effects upon human beings and the environment (Hoegh-Guldberg et al., 2009; Pendleton et al., 2016). In this context, aquaculture, as "the farming of aquatic organisms [with] some form of intervention in the rearing process to enhance production, such as regular stocking, feeding, protection from predators, etc." (FAO, 1988), can and should play a significant role in supporting biodiversity conservation efforts. In particular, through both ex-situ and in-situ research and interventions designed to maintain or assist in the recovery of threatened species, including the integrity of the biotic communities and ecosystems on which they depend.

One species considered at risk of extinction is the Banggai cardinalfish (Pterapogon kauderni), listed as Endangered in the IUCN Red List (Allen and Donaldson, 2007) and a conservation priority 
species at national (MMAF, 2015) and international (Conant, 2015; CITES, 2016a; CITES, 2016b) levels. This small shallow-water paternal mouth-brooding fish with direct development has an endemic distribution of around $5000 \mathrm{~km}^{2}$ and habitat of around 30-34 $\mathrm{km}^{2}$ (Vagelli, 2008; Vagelli, 2011). The Banggai Archipelago, Central Sulawesi Province, Indonesia, comprises over $90 \%$ of the Banggai cardinalfish endemic range and populations, including 18 of 21 reproductively isolated stocks inferred based on DNA analyses (Bernardi and Vagelli, 2004; Hoffman et al., 2005; Vagelli et al., 2009; Ndobe, 2013; Moore et al., 2017a). Banggai cardinalfish associate with benthic organisms which serve as microhabitat; despite strong empirical evidence for an ontogenetic shift in microhabitat (Vagelli, 2004; Ndobe et al., 2008), they remain sedentary and strongly siteattached (Kolm et al., 2005). Banggai cardinalfish population abundance and age structure (parameters indicative of reproductive success) are strongly correlated with the abundance of key microhabitat, in particular sea anemones and Diadema sp. urchins (Ndobe et al., 2005; Ndobe et al., 2013a; Ndobe et al., 2013b; Ndobe et al., 2013c; Ndobe et al., 2013d; Moore et al., 2011; Moore et al., 2012).

Urchins of the Genus Diadema are not only important as microhabitat for other organisms, including the Banggai cardinalfish, but also for their wider ecological role in coastal ecosystems (Macia et al., 2007; Muthiga and McClanahan, 2013; Precht and Precht, 2015). In particular, these urchins are considered as key herbivores which can promote or help maintain coral reef resilience under stresses such as eutrophication, overfishing and climate change related coral bleaching (Carpenter and Edmunds, 2006; Mumby et al., 2006; Mumby et al., 2007). However the past decade has seen a sharp decline in the populations of Diadema urchins across much of the Banggai Archipelago, apparently due to increased exploitation for human consumption and as feed for carnivorous reef fish, with a concurrent decline in (both fished and unfished) Banggai cardinalfish stocks (Moore et al., 2012; Moore et al., 2017a; Moore et al., 2017b; Ndobe et al., 2017). This situation calls for an integrated approach to the conservation of the Banggai cardinalfish and its microhabitat (symbionts). One such is the "BCF Gardens" concept (Ndobe et al., 2013d), based on in-situ breeding (Ndobe and Moore, 2005), using the symbiosis between the Banggai cardinalfish and its microhabitat (especially Diadema sp. urchins and sea anemones) to increase reproductive success through reduced predation, including a reduction in cannibalism of recruits (Ndobe et al., 2013c).

In this context, it is important to identify microhabitat (symbiont) taxa to species level. Studies on the Banggai cardinalfish and its microhabitat highlight the importance of the symbiosis between Banggai cardinalfish and Diadema sp., however which species is not clear. Most studies on Banggai cardinalfish association with urchin microhabitat have recorded data at the genus level (e.g. Lunn and Moreau, 2004; Ndobe et al., 2005; Ndobe et al.,2008; Ndobe et al., 2013a; Ndobe et al., 2013b; Ndobe et al., 2013c; Ndobe et al., 2013d; Moore et al., 2011; Moore et al., 2012). While some publications mention Diadema setosum (e.g. Vagelli and Erdmann, 2002; Vagelli, 2004, Kolm and Berglund, 2003), studies on Diadema sp. phylogeography and species distribution indicate that at least two species, Diadema setosum and Diadema savignyi, could be present in the Banggai Archipelago (Pearse, 1998; Lessios et al., 2001). There was thus a gap in knowledge regarding the identity and number of Diadema urchin species present, as well as their relative abundance and respective level of use as microhabitat by endemic Banggai cardinalfish populations.

This research was performed under a multi-year study on the symbiosis between the Banggai cardinalfish and Diadema sp. urchins. The specific objectives were: (i) to identify the Diadema species associated with endemic Banggai cardinalfish populations in the wild; (ii) to evaluate Banggai cardinalfish preference between the Diadema species found to be present.

\section{Materials and Methods}

The research was conducted during MayJuly 2017. A field study (survey) was conducted within the endemic range of the Banggai cardinalfish in the Banggai Archipelago, Central Sulawesi Province, Indonesia. At each of 5 sites in the Banggai Archipelago (Figure 1), 10 belt transects $(20 \mathrm{~m} \times 5 \mathrm{~m}$, following Ndobe et al., 2008) were randomly placed in known Banggai cardinalfish habitat, comprising a cumulative area of $1000 \mathrm{~m}^{2} / \mathrm{site}$. Experimental research was conducted at the Hasanuddin University Marine Station Hatchery on Barranglompo Island, South Sulawesi Province, Indonesia. 


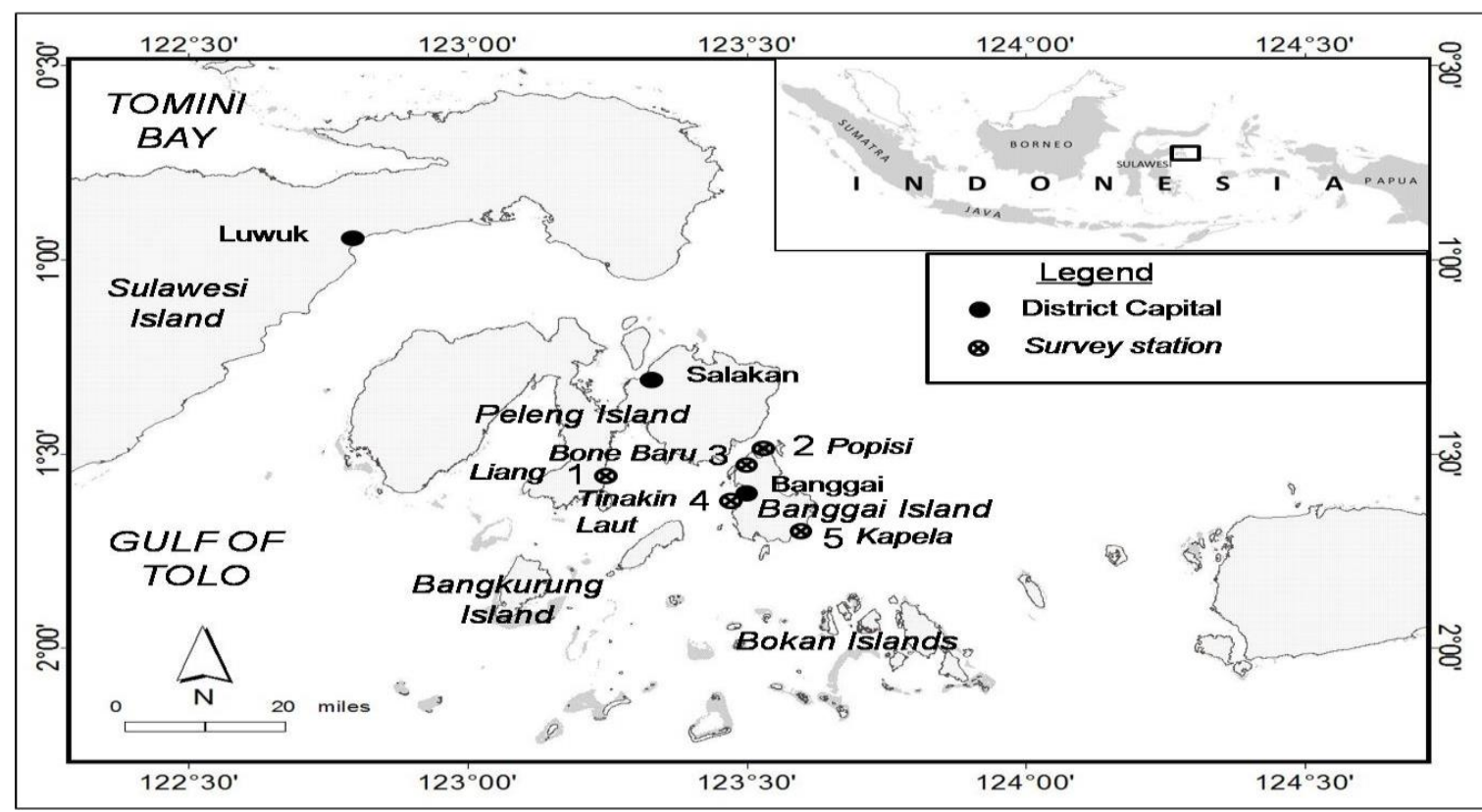

Figure 1. Map of the Banggai Archipelago showing the 5 survey sites (1 Liang, 2 Popisi, 3 Bone Baru, 4 Tinakin Laut, 5 Kapela)

Diadema sp. Identification, Distribution and Relative Abundance

For each group of Diadema sp. within each transect, the number of individual urchins was recorded by species and size. The two size classes used were: (i) large, possibly mature/adult individuals (test diameter > $30 \mathrm{~mm}$ ); and (ii) small, clearly immature juvenile urchins (test diameter $<30 \mathrm{~mm}$ ). The $30 \mathrm{~mm}$ limit was chosen based on the (minimal) data available on Diadema size, growth and maturity reviewed in Muthiga and McClanahan (2007). Identification of Diadema species was based mainly on Chow et al. (2014) and Chow et al. (2016). Individuals were classified using the following external characters: (i) Diadema setosum: orange ring on the anal cone, with five white spots and dotted blue iridophore lines in the naked space of the interambulacral areas; (ii) Diadema savignyi: Yshaped continuous (at least partially double) blue iridophore lines running along the naked space of the interambulacral areas and no orange ring on the anal cone; (iii) undetermined/possible hybrid: any combination other than (i) or (ii).

\section{Banggai Cardinalfish Association with Diadema sp. in The Wild}

The number of Banggai cardinalfish within each transect was recorded by microhabitat association and by size class (recruits/small juveniles $<25 \mathrm{~mm}$, large juveniles/sub-adults 25 -
$42 \mathrm{~mm}$, adults > $42 \mathrm{~mm}$ ) based on standard length (SL). These size classes were based on previous research (Ndobe et al., 2013a; Ndobe et al., 2013b; Ndobe et al., 2013c). For Diadema sp., Banggai cardinalfish associated with each group of urchins were recorded separately. For all biotic microhabitats, the genus (and, where known, the species) was recorded, while for abiotic microhabitat a brief description was recorded.

\section{Banggai Cardinalfish Preference Trials}

Wild-caught Banggai cardinalfish from the Palu Bay introduced population (Moore and Ndobe, 2007) were air-freighted to Makassar, transported to the Field Station, and acclimated (without Diadema microhabitat) before the trials were conducted. Live feed (Artemia salina) was provided twice daily (07:00-0:800 and 16:0017:00 WITA, GMT+8) during the acclimation and trial periods. The trials were conducted in concrete tanks (area $\approx 1.5 \times 1.7 \mathrm{~m}$, water depth $\approx$ $0.5 \mathrm{~m}$ ) supplied with filtered seawater using a continuous throughflow system. Sub-adult (35-42 $\mathrm{mm}$ SL) Banggai cardinalfish (9 individuals) and equal numbers (12 each) of the two Diadema species identified in the field (D. setosum and $D$. savignyi) were placed in each of three replicate trial tanks. The association of each fish ( $D$. savignyi, D. setosum, none) was recorded at hourly intervals (from 06:00 to 18:00 WITA, GMT+8) for three days. 


\section{Data Analysis}

The data were tabulated in Microsoft Excel 2007, and all statistical analyses were conducted in RStudio-1.0.143. Qualitative observations were analysed descriptively. The results were compared with other studies and evaluated in the context of $P$. kauderni conservation and implications for aquaculture, in particular for insitu breeding of the Banggai cardinalfish (Ndobe $\&$ Moore, 2005) and the "BCF Gardens" concept (Ndobe \& Moore, 2013d; Moore and Ndobe, 2017a).

\section{Results}

The field survey results in Table 1 show that urchins exhibiting the characteristics of two species, Diadema setosum and Diadema savignyi, were observed at all sites. In addition, 36 undetermined individuals exhibiting some characteristics of both species (possible hybrids) were observed. Overall, D. setosum was more abundant than $D$. savignyi, however the majority $(64 \%)$ of groups observed comprised both species, while only 8 out of 167 groups contained D. savignyi alone.

Table 1. Species composition, abundance and size class of Diadema sp. $(\mathrm{N}=2964)$

\begin{tabular}{lccccccc}
\hline \multicolumn{1}{c}{ Parameter } & \multirow{2}{*}{ Unit } & Liang & Popisi & Bone Baru & Tinakin Laut & Kapela & Total \\
\hline Transects with Diadema & $\%$ & 50 & 70 & 70 & 100 & 70 & 72 \\
Total Diadema density & $\mathrm{ind} / \mathrm{m}^{2}$ & 0.217 & 0.503 & 0.299 & 0.912 & 1.033 & 0.593 \\
$\begin{array}{l}\text { Juvenile Diadema } \\
\text { (diameter <30 mm) }\end{array}$ & $\%$ & 24.0 & 9.3 & 12.0 & 38.7 & 17.4 & 22.5 \\
$\begin{array}{l}\text { Potentially adult Diadema } \\
\text { (diameter } \geq 30 \mathrm{~mm} \text { ) }\end{array}$ & $\%$ & 76.0 & 90.7 & 88.0 & 61.3 & 82.6 & 77.5 \\
Diadema savignyi & $\mathrm{n}$ & 12 & 118 & 63 & 135 & 95 & 423 \\
& $\%$ & 5.53 & 23.46 & 21.07 & 14.80 & 9.20 & 14.27 \\
Diadema setosum & $\mathrm{n}$ & 205 & 385 & 236 & 777 & 938 & 2541 \\
& $\%$ & 94.47 & 76.54 & 78.93 & 85.20 & 90.80 & 85.73 \\
Suspected hybrids & $\mathrm{n}$ & 5 & 5 & 5 & 9 & 12 & 36 \\
& $\%$ & 2.25 & 0.98 & 1.64 & 0.98 & 1.15 & 1.20 \\
\hline
\end{tabular}

The observed associations of Banggai cardinalfish with the two Diadema urchin species and other microhabitat types are shown in Table 2. All three Banggai cardinalfish size classes (from recent recruits to adults) were observed associated with mono-species groups of each Diadema species as well as (predominantly) mixed species groups (Figure 2a). Banggai cardinalfish association with microhabitat types other than the two Diadema species differed between age/size groups. Recruits and (mostly smaller) juveniles were associated with other sea urchins of the Family Diadematidae (Echinothrix sp. and Astropyga radiata), sea anemones (Entacmea quadricolor, Heteractis crispa, Actinodendron sp., Heteractis magnifica, Stichodactyla gigantea), hard corals of the genus Heliofungia, and the upside-down jellyfish (Cassiopea sp.). Adult Banggai cardinalfish were commonly associated with corals, mostly branching forms. Recorded microhabitat organisms included 8 hard coral genera (Acropora, Seriatopora, Stylophora, Goniopora, Echinopora, Hydnophora, Heliofungia, Porites), branching and foliose forms of fire coral (Millepora sp.), soft corals (Sinularia sp.), branching sponges, and seagrass (Enhalus acaroides). At two sites (Tinakin Laut and under the pier at Kapela), Banggai cardinalfish were observed (possibly temporarily) associated with abiotic microhabitat, including manmade structures and marine debris.

The Banggai cardinalfish preference trial results are summarised in Table 3. An example of a typical observation is shown in Figure $2 b$. There was no mortality of experimental animals during the trial period. The urchin groupings and Banggai cardinalfish associations varied throughout the observation period, however there was no significant difference between the number of Banggai cardinalfish associated with each urchin species overall, between days, or for any of the 3 replicates $(p>0.05)$. On average $( \pm$ standard deviation), $42.22 \% \pm 10.03 \%$ were associated with Diadema savignyi, 42.03\% \pm $10.19 \%$ with $D$. setosum and $15.75 \% \pm 13.47 \%$ with neither. Banggai cardinalfish not associated with either urchin species were either actively feeding (45\%), moving through the water but not obviously feeding (34\%), or stationary, usually in a corner of the tank $(21 \%)$. 
Table 2. Observed Banggai cardinalfish $(\mathrm{BCF})$ microhabitat use $(\mathrm{N}=4259)$

\begin{tabular}{|c|c|c|c|c|c|c|c|}
\hline \multirow{2}{*}{ Parameter } & \multirow{2}{*}{ Unit } & \multicolumn{5}{|c|}{ Survey Site } & \multirow[b]{2}{*}{ Total } \\
\hline & & Liang & Popisi & Bone Baru & Tinakin Laut & Kapela & \\
\hline Transects with BCF & $\%$ & 50 & 70 & 70 & 100 & 70 & 72 \\
\hline Total BCF density & $\underset{2}{\mathrm{ind} / \mathrm{m}}$ & 0.266 & 1.174 & 1.186 & 0.924 & 0.709 & 0.8518 \\
\hline $\begin{array}{l}\text { BCF recruits/small } \\
\text { juveniles }(<25 \mathrm{~mm} \mathrm{SL})\end{array}$ & $\%$ & 9.02 & 11.07 & 20.40 & 13.31 & 10.16 & 13.88 \\
\hline $\begin{array}{l}\text { Juvenile/sub-adult BCF } \\
(25-42 \mathrm{~mm} \mathrm{SL})\end{array}$ & $\%$ & 34.96 & 25.21 & 39.88 & 42.75 & 20.17 & 32.87 \\
\hline Adult BCF (> 42 mm SL) & $\%$ & 56.02 & 63.71 & 39.71 & 43.94 & 69.68 & 53.25 \\
\hline \multicolumn{8}{|c|}{ BCF in Diadema sp. (DD) microhabitat } \\
\hline Proportion of all BCF & $\%$ & 46.24 & 79.81 & 23.95 & 77.81 & 10.30 & 50.15 \\
\hline $\begin{array}{l}\text { BCF recruits/small } \\
\text { juveniles }(<25 \mathrm{~mm} \mathrm{SL})\end{array}$ & $\%$ & 2.44 & 8.75 & 21.13 & 4.87 & 47.95 & 10.07 \\
\hline $\begin{array}{l}\text { Juvenile/sub-adult BCF } \\
(25-42 \mathrm{~mm} \mathrm{SL})\end{array}$ & $\%$ & 57.72 & 19.21 & 43.66 & 45.76 & 15.07 & 33.47 \\
\hline Adult BCF (> $42 \mathrm{~mm} \mathrm{SL})$ & $\%$ & 39.84 & 72.04 & 35.21 & 49.37 & 36.99 & 56.46 \\
\hline \multicolumn{7}{|c|}{ Main other microhabitat types $(\mathrm{X}=$ observed, $-=$ not observed $)$} & No. sites \\
\hline Echinothrix sp. & & $\mathrm{X}$ & $\mathrm{X}$ & $\mathrm{X}$ & $\mathrm{X}$ & $\mathrm{X}$ & 5 \\
\hline Astropyga radiata & & - & - & $\mathrm{X}$ & - & - & 1 \\
\hline Entacmea quadricolor & & $\mathrm{X}$ & - & $\mathrm{X}$ & $\mathrm{X}$ & $\mathrm{X}$ & 4 \\
\hline Heteractis crispa & & - & - & $\mathrm{X}$ & - & $\mathrm{X}$ & - \\
\hline Actinodendron sp. & & - & $X$ & $\mathrm{X}$ & $\mathrm{X}$ & - & 3 \\
\hline Other sea anemones & & - & - & $\mathrm{X}$ & - & - & 1 \\
\hline Acropora sp. (branching fo & & $\mathrm{X}$ & $\mathrm{X}$ & $\mathrm{X}$ & $\mathrm{X}$ & - & 4 \\
\hline Seriatopora/Stylophora sp. & & - & $\mathrm{X}$ & $\mathrm{X}$ & - & - & 2 \\
\hline Porites sp. (branching form & & $\mathrm{X}$ & $\mathrm{X}$ & - & - & - & 2 \\
\hline Other branching corals & & $\mathrm{X}$ & - & - & - & - & 1 \\
\hline Goniopora sp. (semi-massi & & $\mathrm{X}$ & $\mathrm{X}$ & $\mathrm{X}$ & - & - & 3 \\
\hline Heliofungia sp. & & $\mathrm{X}$ & - & - & - & $\mathrm{X}$ & 2 \\
\hline Sinularia sp. soft coral & & $\mathrm{X}$ & - & $\mathrm{X}$ & - & - & 1 \\
\hline Branching sponges & & - & $\mathrm{X}$ & - & - & $\mathrm{X}$ & 2 \\
\hline Cassiopea sp. jellyfish & & - & - & - & $\mathrm{X}$ & - & 1 \\
\hline Enhalus acaroides & & - & $\mathrm{X}$ & - & $\mathrm{X}$ & - & 2 \\
\hline Abiotic substrate/structures & & - & - & - & $\mathrm{X}$ & $\mathrm{X}$ & 2 \\
\hline
\end{tabular}

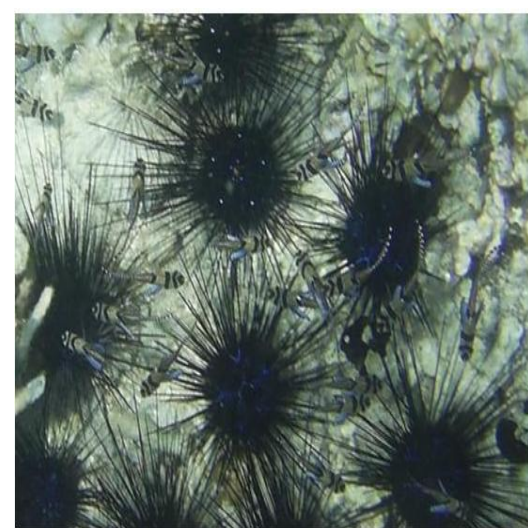

(a)

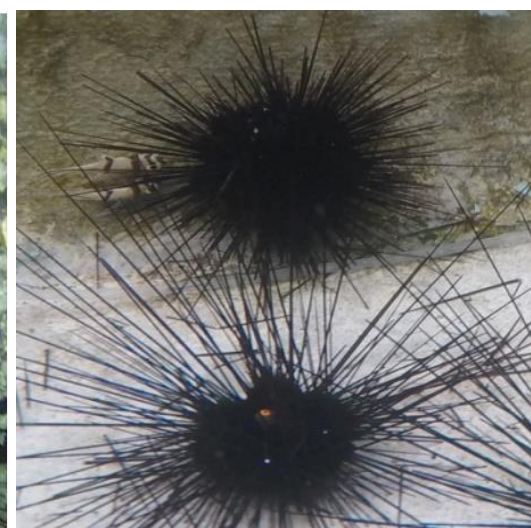

$\left(\mathrm{b}_{1}\right)$

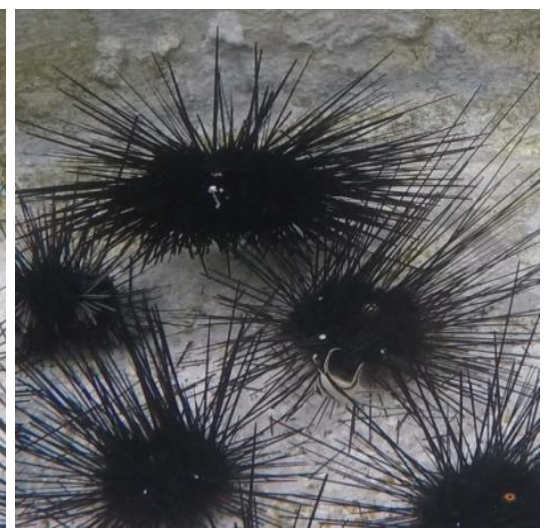

$\left(b_{2}\right)$

Figure 2. Banggai cardinalfish associated with two Diadema species: a. in the wild, at Bone Baru and b. during the preference trials $\left(\mathrm{b}_{1}, 2\right.$ fish associated with Diadema savignyi; $\mathrm{b}_{2}, 1$ fish associated with Diadema setosum). 
Table 3. Banggai cardinalfish Diadema sp. preference trial results.

\begin{tabular}{lccc}
\hline \multirow{2}{*}{ Period } & \multicolumn{3}{c}{ Proportion $(\% \pm \mathrm{SD})$ of Banggai cardinalfish associated with } \\
\cline { 2 - 4 } & Diadema savignyi & Diadema setosum & None \\
\hline Trial (day 1-3) & $3.80 \pm 0.90$ & $3.79 \pm 0.92$ & $1.42 \pm 1.21$ \\
$08: 00$ & $3.22 \pm 0.67$ & $3.11 \pm 0.60$ & $2.67 \pm 1.12$ \\
\hline
\end{tabular}

${ }^{1}$ The linear model (lm function) analysis implemented in $\mathrm{R}$ did not reveal any significant difference between days or between replicates $(\mathrm{P}>0.05)$; however there was a significant difference between 08:00 observations and all other time periods (06:00-0:700 and 09:00-18:00)

Table 4. Some implications of the study results for Banggai cardinalfish (BCF) conservation, including the potential role of aquaculture.

\begin{tabular}{|c|c|c|c|}
\hline No. & Aspect & Implications & Recommendation \\
\hline 1 & $\begin{array}{l}\text { Genetic } \\
\text { biodiversity and } \\
\text { connectivity }\end{array}$ & $\begin{array}{l}\text { Diadema urchins (wild caught or } \\
\text { captive breeding) for re-stocking } \\
\text { should be from same genetic stock as } \\
\text { those at target site }\end{array}$ & $\begin{array}{l}\text { - Research on Diadema sp. genetic } \\
\text { connectivity/stocks } \\
\text { - Careful selection of Diadema sp. } \\
\text { broodstock }\end{array}$ \\
\hline 2 & $\begin{array}{l}\text { Species diversity } \\
\text { (Diadema) }\end{array}$ & $\begin{array}{l}\text { Diadema population species } \\
\text { composition varies between sites and } \\
\text { within sites (e.g. between habitat } \\
\text { types) } \\
\text { - Interventions should avoid causing } \\
\text { major shifts in species balance }\end{array}$ & $\begin{array}{l}\text { - Research on the distribution of each } \\
\text { Diadema sp. at multiple scales and } \\
\text { across habitat types } \\
\text { - Need to develop breeding and } \\
\text { release protocols for each species } \\
(\text { D. savignyi \& D, setosum })\end{array}$ \\
\hline 3 & $\begin{array}{l}\text { Ecosystem health, } \\
\text { diversity and } \\
\text { balance }\end{array}$ & $\begin{array}{l}\text { Diadema urchins are known to play } \\
\text { important ecological roles which are } \\
\text { density dependent; however } \\
\text { knowledge on the roles of } D \text {. } \\
\text { savignyi and } D \text {. setosum is limited } \\
\text { and contradictory }\end{array}$ & $\begin{array}{l}\text { - Research on the ecological roles of } \\
\text { each Diadema species and density } \\
\text { effects (including carrying } \\
\text { capacity) in the context of } \\
\text { ecosystem health and resilience, } \\
\text { etc. }\end{array}$ \\
\hline 4 & $\begin{array}{l}\text { Research on the } \\
\text { BCF - Diadema } \\
\text { symbiosis }\end{array}$ & $\begin{array}{l}\text { - BCF do not appear to exhibit } \\
\text { preference or different behaviour } \\
\text { with the two Diadema species } \\
\text { - Each Diadema species will have } \\
\text { different habitat niches and most } \\
\text { likely respond differently to } \\
\text { environmental cues and changes, } \\
\text { whether natural or experimental }\end{array}$ & $\begin{array}{l}\text { - Use of "samples of convenience" } \\
\text { (locally abundant urchins) for some } \\
\text { research (e.g. many BCF } \\
\text { behavioural studies) } \\
\text { - Species will be important where } \\
\text { environmental variables are a factor } \\
\text { (e.g. studies on climate } \\
\text { change/ocean acidification) }\end{array}$ \\
\hline
\end{tabular}

\section{Discussion}

The results show that at least two sea urchin species of the Genus Diadema are present in the Banggai Archipelago. As reported by De Beer (1990) in the Spermonde Archipelago and Pearse (1998) in North Sulawesi and the Sangihe Islands, the relative abundance of the two species varies between sites. These variations could reflect the influence of intrinsic factors (e.g. reproductive biology and larval dispersal patterns), external factors (e.g. levels of pollution and/or exposure to wave action and currents), and stochastic factors. Diadema urchins are heavily exploited in the Banggai Archipelago (Moore et al., 2012; Ndobe et al., 2017). It is not known whether the fishers or consumers recognise or have any preference between Diadema species; however it is possible that, in addition to overall abundance, the relative abundance of each species could, at least to some extent, be affected by Diadema exploitation patterns.

Both De Beer (1990) and Pearse (1998) found that relative abundance appeared to be related to environmental conditions. D. setosum seemed to be more common than $D$. savignyi at sites with higher levels of terrestrial or anthropogenic influence, particularly sedimentation, eutrophication, and other forms of pollution. Conversely, D. savignyi has been reported as 
more common at sites further from large islands or human settlements, typically with clearer waters, and often more exposed to wave action. The seemingly greater ability of $D$. savignyi to cope with relatively violent water movement is possibly related to the finding by Muthiga (2003) that $D$. savignyi can outcompete $D$. setosum in securing protective microhabitat such as crevices within or between coral colonies and rocks. In addition, Coppard and Campbell (2007) report differences in grazing preferences between Diadematid urchins, including the two species in this study. Thus, it seems likely that environmental factors may be important in determining Diadema urchin community composition in the Banggai Archipelago.

The presence of apparent hybrids between the two species is consonant with reports from other areas in the Indo-pacific (Lessios and Pearse, 1996; Lessios 2007). Some studies, based on morphometric (DNA) and genetic analyses, indicate that external morphology is not always a reliable indication of species (Pearse, 1970; Pearse, pers. comm., 2016), and that hybrids can be fertile as backcrosses have been identified (Lessios and Pearse, 1996). Although phylogeographic connectivity of Diadema sp. has been studied over the wider Indo-Pacific area, including Malaysia, Philippines, Australia and Papua New Guinea (Lessios et al., 2001), to date there are no data from Indonesia, at the centre of the Coral Triangle marine biodiversity "hotspot". Genetic (DNA) studies to fill this gap could provide valuable information on connectivity and help inform ecosystem-based conservation of the Banggai cardinalfish and its habitat, including efforts to assist the recovery of Diadema stocks, in particular through the development of captive breeding of Diadema sp. urchins.

The high level (84.25\%) of Banggai cardinalfish association with Diadema sp. throughout the preference trial, in the absence of any threat of predation, reinforces the importance of this symbiosis. The lack of any consistent preference for either $D$. setosum or $D$. savignyi when equal numbers of both species were present indicates that, at least under current environmental conditions, the species of Diadema present is unlikely to significantly affect Banggai cardinalfish conservation outcomes. It also indicates that many behavioural studies to further elucidate the symbiosis between the Banggai cardinalfish and Diadema could be carried out using whichever urchin species was more convenient, e.g. through local abundance or greater adaptability to a given controlled environment. However a note of caution is felt necessary regarding studies in the wild or where environmental variables are a key part of the study (e.g. climate change and ocean acidification impact studies). Based on empirical (field) studies on Diadema species (De Beer, 1990; Pearse, 1998) as well as experimental research on sea urchins more generally (e.g. Brennand et al., 2010; Dorey et al., 2013; Sherman, 2015), the responses of the two Diadema species to environmental change are likely to have significant (mostly negative) consequences for fitness, and could be very different from one another.

The lack of significant difference between the observations by day or replicate strengthens the validity of the result. The significant difference in association at 08:00 compared to other times of day was probably related to the time of first daily feed, between 07:00 and 08:00. Throughout the experiment, individuals not associated with Diadema sp. urchins tended to exhibit typical feeding behaviour, i.e. short bursts of speed accompanied with mouth opening and closing, including $83 \%$ of individuals observed during the 08:00 time period. The percentage was lower (typically around 50\%) at other times of day, including after the afternoon feed (between 16:00 and 17:00). Non-feeding unassociated fish were either swimming actively (possibly moving between con-specific groups or urchin clumps) or sedentary in a corner of the tank. Reasons for the higher feeding activity after the morning feed could include greater hunger after a night with little or no feeding opportunity, while some feeding on the remaining (live) morning feed probably occurred throughout much of the day. Thus it is logical that the afternoon feed would not elicit as large a response in terms of concentrated active feeding behaviour as the morning feed.

While the survey and experimental results do not indicate any preference by the Banggai cardinalfish for either sea urchin species, the presence of both Diadema species at all survey sites has important implications for many aspects of genetic, species and ecosystem conservation, including interventions where aquaculture could or should play a role. Lessons learned from the (still experimental) culture and release to the wild of D. antillarum in the Caribean (Moe, 2010; Moe pers.com. 2015) could inform such processes in the Indo-Pacific, and in particular the Banggai Archipelago. Aspects of particular 
concern in this context include biodiversity at inter- and intra-species levels and connectivity. Table 4 presents a brief overview of some implications of this study for biodiversity conservation, including conservation-oriented aquaculture.

In conclusion, this study shows that two species of the Genus Diadema (Diadema savignyi and Diadema setosum) are important as microhabitat (symbionts) of the endangered Banggai cardinalfish (Pterapogon kauderni) within its endemic range. The experimental observations showed no significant preference by Banggai cardinalfish for either $D$. savignyi or $D$. setosum. These results indicate that $D$. savignyi and D. setosum could be used impartially in further research on in-situ breeding to facilitate the recovery of Banggai cardinalfish stocks. However, any Diadema sp. stock recovery measures should take genetic connectivity and structure into account and, furthermore, should aim to maintain the balance between the two urchin species.

\section{Acknowledgement}

We would like to thank the Ministry of Research and Higher Education of Indonesia for support under Letter of Agreement for PostDoctoral Research, No. 703.b/UN28.2/PL/2017, dated 27th April, 2017. Many thanks to all who assisted during this study, in the Banggai Archipelago, at the Barranglompo Marine Station, in Makassar, and in Palu. We also wish to thank two annonymous reviewers whose input helped us to improve this manuscript.

\section{References}

Allen, G.R. and T.J. Donaldson. 2007. Pterapogon kauderni. The IUCN Red List of Threatened Species 2007: e.T63572A12692964. Doi: 10.2305/IUCN.UK.2007.RLTS.T63572A12 692964.en.

Barnosky, A.D. 2014. Palaeontological evidence for defining the Anthropocene. In: Waters, C. N., J.A. Zalasiewicz, M. Williams, M.A. Ellis, and A.M. Snelling (Eds), A Stratigraphical Basis for the Anthropocene. Geological Society, London, Special Publications, 395: 149-165. Doi: 10.1144/SP395.6.

Bernardi, G. and A. Vagelli. 2004. Population structure in Banggai cardinalfish, Pterapogon kauderni, a coral reef species lacking a pelagic larval phase. Marine Biology, 145: 803-810. Doi: 10.1007/ s00227-004-1355-1.
Brennand, H.S., N. Soars, S.A. Dworjanyn, A.R. Davis, and M. Byrne. 2010. Impact of ocean warming and ocean acidification on larval development and calcification in the sea urchin Tripneustes gratilla. PLoS One, 5(6): e11372. Doi:10.1371/journal.pone. 0011372.

Carpenter, R.C. and P.J. Edmunds. 2006. Local and regional scale recovery of Diadema promotes recruitment of scleractinian corals. Ecology Letters, 9(3): 268-277. Doi: 10.1111/j.1461-0248.2005.00866.x.

Cheung W.W.L., V.W.Y. Lam, J.L. Sarmiento, K. Kearney, R. Watson, and D. Pauly. 2009. Projecting global marine biodiversity impacts under climate change scenarios. Fish and Fisheries, 10: 235-251. Doi: 10.1111/j.1467-2979.2008.00315.x.

Chow, S., Y. Kajigaya, H. Kurogi, K. Niwa, and T. Shibuno. 2014. On the fourth diadema species (Diadema-sp) from Japan. Plos One, 9(7), e102376 (1-9). Doi: 10.1371/journal .pone. 0102376.

Chow, S., K. Konishi, M. Mekuchi, Y. Tamaki, K. Nohara, M. Takagi, K. Niwa, W. Teramoto, H. Manabe, H. Kurogi, S. Suzuki, D. Ando, T. Jinbo, M. Kiyomoto, M. Hirose, M. Shimomura, A. Kurashima, T. Ishikawa, and S. Kiyomoto. 2016. DNA barcoding and morphological analyses revealed validity of Diadema clarki Ikeda, 1939 (Echinodermata, Echinoidea, Diadematidae). ZooKeys, 585: 1-16. Advance online publication. Doi: 10.3897/zookeys.585.8161.

CITES (Convention on International Trade in Endangered Species of Wild Fauna and Flora) 2016a. CoP 17 Proposal 46 Inclusion of Pterapogon kauderni in Appendix II. European Union. https://cites. org/sites/default/files/eng/cop/17/prop/0602 16/E-CoP17-Prop-46.pdf.

CITES (Convention on International Trade in Endangered Species of Wild Fauna and Flora). 2016c. CoP17 Com. I. 32. Draft decisions on the Banggai cardinalfish (Pterapogon kauderni). https://cites.org/ sites/default/files/eng/cop/17/Com_I/E-CoP 17-Com-I-32.pdf.

Conant, T.A. 2015. Banggai Cardinalfish, Pterapogon kauderni. Endangered Species Act Draft Status Review Report. National Marine Fisheries Service. National Oceanic and Atmospheric Administration (NOAA), Silverspring, Maryland, USA, 40 p. http://www.fisheries.noaa.gov/pr/species/St atus\%20Reviews/banggaii_cardinalfish_sr_ 2015.pdf.

Coppard, S.E. and A.C. Campbell. 2007. Grazing preferences of diadematid echinoids in Fiji. Aquatic Botany, 86(3): 204-212. Doi: 10.1016/j.aquabot.2006.10.005. 
Crutzen, P.J. 2002. Geology of mankind: the anthropocene. Nature, 415: 23. Doi: $10.1038 / 415023 \mathrm{a}$

De Beer, M. 1990. Distribution patterns of regular sea urchins (Echinodermata: Echinoidea) across the Spermonde Shelf, SW Sulawesi (Indonesia). In: D. Ridder, Dubois, Lahaye, and Jangoux (Eds.), Echinoderm Research. Balkerna, Rotterdam, pp. 165-169.

Dirzo, R., H.S. Young, M. Galetti, G. Ceballos, N.J.B. Isaac, and B. Collen. 2014. Defaunation in the Anthropocene. Science, 345: 401-406. Doi: $10.1126 /$ science. 1251817.

Dorey, N., P. Lançon, M. Thorndyke, and S. Dupont. 2013. Assessing physiological tipping point of sea urchin larvae exposed to a broad range of $\mathrm{pH}$. Global Change Biology, 19: 3355-3367. Doi: 10.1111/gcb. 12276.

Ellis, E.C. 2011. Anthropogenic transformation of the terrestrial biosphere. Philosophical Transactions of the Royal Society of London Series A, 369: 1010-1035. Doi: 10.1098/rsta.2010.0331.

FAO (Food and Agriculture Organisation of the United Nations). 1988. Definition of aquaculture, Seventh Session of the IPFC Working Party of Expects on Aquaculture, IPFC/WPA/WPZ, pp. 1-3, RAPA/FAO, Bangkok, Thailand.

Hoegh-Guldberg, O., E.S. Poloczanska, W. Skirving, and S. Dove. 2017. Coral reef ecosystems under climate change and ocean acidification. Frontiers in Marine Science, 4(158):1-20. Doi: 10.3389/fmars.2017. 00158.

Hoegh-Guldberg, O., H. Hoegh-Guldberg, J.E.N. Veron, A. Green, E.D. Gomez, J. Lough, M. King, H.L. Ambariyanto, J. Cinner, G., Dews, G., Russ, H.Z. Schuttenberg, E.L. Penaflor, C.M. Eakin, T.R.L. Christensen, M. Abbey, F. Areki, R.A. Kosaka, A. Tewfik, and J. Oliver. 2009. The Coral Triangle and Climate Change: Ecosystems, People and Societies at Risk. WWF Australia, Brisbane, Australia. 276 p.

Hoffman, E.A., N. Kolm, A. Berglund, J.R. Arguello, and A.G. Jones. 2005. Genetic structure in the coral-reef-associated Banggai cardinalfish, Pterapogon kauderni. Molecular Ecology, 14: 1367-1375. Doi: 10.1111/j.1365-294X.2005.02538.x.

IPCC (International Panel on Climate Change). 2014. Climate Change 2014: Synthesis Report. Contribution of Working Groups I, II and III to the Fifth Assessment Report of the Intergovernmental Panel on Climate Change [Core Writing Team, R.K. Pachauri and L.A. Meyer (Eds.)]. IPCC, Geneva, Switzerland, $151 \mathrm{p}$.

Jackson, J.B.C. 2008. Ecological extinction and evolution in the brave new ocean.
Proceedings of the National Academy of Sciences, 105(S1): 11458-11465. Doi: 10.1073/pnas.0802812105

Jones, M.C. and W.W. Cheung. 2014. Multi-model ensemble projections of climate change effects on global marine biodiversity. ICES Journal of Marine Science, 72(3): 741-752. Doi:10.1093/icesjms/fsu172.

Kolm, N. and A. Berglund. 2003. Wild populations of a reef fish suffer from the "nondestructive" aquarium trade fishery. Conservation Biology, 17(3): 910-914.

Kolm N., EA Hoffman, J. Olsson, A. Berglund, and A.G. Jones. 2005. Group stability and homing behavior but no kin group structures in a coral reef fish. Behavioral Ecology, 16: 521-527. Doi:10.1093/beheco /ari022.

Lessios, H.A. 2007. Reproductive isolation between species of sea urchins. Bulletin of Marine Science, 81(2), 191-208.

Lessios, H.A., and J.S. Pearse. 1996. Hybridization and introgression between Indo-Pacific species of Diadema. Marine Biology, 126(4): 715-723.

Lessios, H.A., B.D. Kessing, and J.S. Pearse. 2001. Population structure and speciation in tropical seas: global phylogeography of the sea urchin Diadema. Evolution, 55(5): 955975. Doi: 10.1554/0014-3820(2001)055 [0955: PSASIT]2.0.CO;2.

Lunn, K.E. and A.M. Moreau. 2004. Unmonitored trade in marine ornamental fishes: the case of Indonesia's Banggai Cardinalfish (Pterapogon kauderni). Coral Reefs, 23: 344-341. Doi: 10.1007/s00338-004-0393-y.

Maciá S., M.P. Robinson, and A. Nalevanko. 2007. Experimental dispersal of recovering Diadema antillarum increases grazing intensity and reduces macroalgal abundance on a coral reef. Marine Ecology Progress Series, 348: 173-182. Doi: 10.3354/meps 06962.

MMAF (Ministry for Marine Affairs and Fisheries of the Republic of Indonesia). 2015. Regulation of the Ministry for Marine Affairs and Fisheries of the Republic of Indonesia Number 45 of 2015. Strategic Plan of Ministry for Marine Affairs and Fisheries 2015-2019. Ministry for Marine Affairs and Fisheries of the Republic of Indonesia, Jakarta. http://roren.kkp.go.id/ arsip/file/137/renstra-kkp-2015-2019permen-kp-no.-45-th.-2015.pdf/.

Moe, M.A., K. Leber, D. Vaghan, and T. Capo. 2010. Returning the Keystone Herbivore, Diadema antillarum, to Florida Coral Reefs. Presentation at Linking Science to Management, Duck Key, Florida, October 19-22 2010. https://conference.ifas.ufl.edu/ 
floridakeys/Presentations/PDFS/Session $\% 2$ 01/Moe\%20-\%20Diadema\%20culture\%20$\% 20$ session\%201.pdf.

Molinos, J.G., B.S. Halpern, D.S. Schoeman, C.J., Brown, W. Kiessling, P.J. Moore, J.M. Pandolfi, E.S. Poloczanska, A.J. Richardson, and M.T. Burrows. 2016. Climate velocity and the future global redistribution of marine biodiversity. Nature Climate Change, 6(1): 83-88. Doi: 10.1038/nclimate2769.

Moore A. and S. Ndobe. 2007. Discovery of an introduced Banggai Cardinalfish population in Palu Bay, Central Sulawesi, Indonesia. Coral Reefs, 26: 569. Doi: 10.1007/s00338007-0227-9.

Moore, A., S. Ndobe, and M. Zamrud. 2011. Monitoring the Banggai Cardinalfish, an Endangered Restricted Range Endemic Species. Journal of Indonesian Coral Reefs, 1(2): 99-113.

Moore, A., S. Ndobe, A.I.M. Salanggon, Ederyan, and A. Rahman. 2012. Banggai Cardinalfish ornamental fishery: the importance of microhabitat. Proceedings of the 12th International Coral Reef Symposium, Cairns, Australia, 9-13 July 2012, 13C_1, 5 p. http://www.icrs2012.com/proceedings/manus cripts/ICRS2012_13C_1.pdf

Moore, A., S. Ndobe, and J. Jompa. 2017a. Konsep konservasi berbasis kawasan dalam rangka pemulihan populasi endemik Banggai cardinalfish (Pterapogon kauderni). Coastal and Ocean Journal, 1(20): 63-72.

Moore, A., S. Ndobe, and J. Jompa. 2017b. Fingerprints of the Anthropocene: the 2016 coral bleaching event in an equatorial Archipelago. Proceedings of the 4th International Marine and Fisheries Symposium, Makassar, 20 May 2017. Hasanuddin University, Makassar, Indonesia, pp. 66-86.

Mumby, P.J., J.D. Hedley, K. Zychaluk, A.R. Harborne, and P.G. Blackwell. 2006. Revisiting the catastrophic die-off of the urchin Diadema antillarum on Caribbean coral reefs: Fresh insights on resilience from a simulation model. Ecological Modelling, 196: 131-149. Doi: 10.1016/j.ecolmodel.2005.11. 035 .

Mumby, P.J., A. Hastings, and H.J. Edwards. 2007. Thresholds and the resilience of Caribbean coral reefs. Nature, 450: 98-101. Doi: 10.1038/nature06252.

Muthiga, N.A. 2003. Coexistence and reproductive isolation of the sympatric echinoids Diadema savignyi Michelin and Diadema setosum (Leske) on Kenyan coral reefs. Marine Biology, 143: 669-677. Doi: 10.1007/s00227003-1095-7.

Muthiga, N.A. and T.R. McClanahan. 2007. Ecology of Diadema. In: Lawrence, J.M.
(Ed.), Edible Sea Urchins: Biology and Ecology. Developments in Aquaculture and Fisheries Science, 37: 205-225.

Muthiga, N.A. and T.R. McClanahan. 2013. Diadema. In: Lawrence J.M. (Ed.), Edible Sea Urchins: Biology and Ecology. Elsevier, pp. 257-274. Doi: 10.1016/B9780-12-396491-5.00018-6.

Ndobe, S. 2013. Biological and ecological of Banggai Cardinalfish, Pterapogon kauderni (An study of fish conservation management). Doctoral Dissertation. Postgraduate Program, Faculty of Fisheries and Marine Science, Brawijaya University, Malang, Indonesia. 397+xxviii p.

Ndobe S. and A. Moore. 2005. The potential and importance of In-situ development of Pterapogon kauderni (Banggai Cardinalfish). InfoMAI, 4 (2): 9-14.

Ndobe, S., A. Moore, and A. Supu. 2005. Sulawesi Case Study - Banggai Kepulauan. Pages 5143 \& 165-229. In: The Indonesian Ornamental Fish Trade: Case Studies and Options for Improving Livelihoods while Promoting Sustainability in Banggai and Banyuwangi. The International Seafood Trade: Supporting Sustainable Livelihoods Among Poor Aquatic Resource Users in Asia (EC Prep Project EP/RO3/R14). Poseidon and Network of Aquaculture Centres in Asia (NACA) STREAM, 286 p. Retrieved from: http://www.enaca. org/publications/livelihoods-gender-social/ stream/regional/EcprepIndonesia.pdf .

Ndobe, S., Madinawati, and A. Moore. 2008 Ontogenetic shif in the microhabitat of the endemic Banggai cardinalfish Pterapogon kauderni. Jurnal Mitra Bahari, 2(2): 32-55.

Ndobe, S., D. Setyohadi, E.Y. Herawati, Soemarno, A. Moore, M.D. Palomares, and D. Pauly. 2013a. Life History of Banggai Cardinalfish (Pterapogon kauderni; Pisces, Apogonidae) in Banggai Islands and Palu Bay, Sulawesi, Indonesia. Acta Ichthyologica Et Piscatoria, 43(3): 237-250. Doi: 10.3750/AIP2013.43.3.08.

Ndobe, S., A. Moore, Nasmia, Madinawati, and N. Serdiati. 2013b. The Banggai cardinalfish: an overview of local research (2007-2009). Galaxea, Journal of Coral Reef Studies, (2013, Special Issue): 243-252.

Ndobe, S., I. Widiastuti, and A. Moore. 2013c. Sex ratio and predation on recruit in the marine ornamental Banggai cardinalfish (Pterapogon kauderni). Prosiding Konferensi Akuakultur Indonesia 2013. http://epaper.aquaculturemai.org/upload/2.\%20Ndobe\%20dkk\%20K AI\%202013.pdf

Ndobe, S. A. Moore, A.I.M. Salanggon, Muslihudin, D. Setyohadi, E.Y. Herawati, and Soemarno. 2013d. Banggai cardinalfish 
(Pterapogon kauderni) management and ecosystem-based approach. Marine Fisheries, 4(2): 115-126.

Ndobe, S., A. Moore, and J. Jompa. 2017. Status of and threats to microhabitats of the endangered endemic banggai cardinalfish (Pterapogon kauderni). Coastal and Ocean Journal, 1(2): 73-82.

Pearse, J.S. 1970. Reproductive perodicities of IndoPacific Invertebrates in the Gulf of Suez. III. The Echinoid Diadema setosum (Leske). Bulletin of Marine Science, 20(3): 697-720.

Pearse, J.S. 1998. Distribution of Diadema savignyi and D. setosum in The Tropical Pacific. Echinoderms: San Francisco, A.A. Balkema, Rotterdam, 1998:777-82.

Pendleton, L., A. Comte, C. Langdon, J.A. Ekstrom, S.R. Cooley, L. Suatoni, M.W. Beck, L.M. Brander, L. Burke, J.E. Cinner, C. Doherty, P.E.T. Edwards, D. Gledhill, L-Q. Jiang, R.J. van Hooidonk, L. Teh, G.G. Waldbusser, and J. Ritter. 2016. Coral reefs and people in a high-CO2 world: where can science make a difference to people?. Plos One, 11(11): e0164699. Doi: 10.1371/ journal.pone. 0164699 .

Precht, L.L. and W.F. Precht. 2015. The sea urchin Diadema antillarum - keystone herbivore or redundant species?. Peer J. Preprints, 2015(Dec): 1-48. Doi: 10.7287/peerj. preprints. $1565 \mathrm{v} 2$.

Schwägerl, C. 2014. The Anthropocene: The Human Era and How It Shapes Our Planet. Synergetic Press, London, 249 p.

Sherman, E. 2015. Can sea urchins beat the heat? Sea urchins, thermal tolerance and climate change. Peer J., 3:e1006. Doi: 10.7717/ peerj.1006.

Steffen, W., J. Grinevald, P. Crutzen, and J. McNeill. 2011. The Anthropocene: conceptual and historical perspectives. Philosophical Transactions of the Royal
Society Series A, 369: 842-867. Doi: 10.1098/rsta.2010.0327.

Steffen, W., W. Broadgate, L. Deutsch, O, Gaffney, and C. Ludwig. 2015. The trajectory of the Anthropocene: the great acceleration. The Anthropocene Review, 1-18. Doi: 0.1177/ 2053019614564785.

Vagelli, A.A. 2004. Ontogenetic Shift in Habitat Preference by Pterapogon kauderni, a Shallow Water Coral reef Apogonid with Direct Development. Copeia, 2004(2): 364369. Doi: 10.1643/CE-03-059R2.

Vagelli A.A. 2008. The unfortunate journey of Pterapogon kauderni: A remarkable apogonid endangered by the international ornamental fish trade, and its case in CITES. SPC Live Reef Fish Information Bulletin, 18: 17-28.

Vagelli, A.A. 2011. The Banggai Cardinalfish: Natural History, Conservation, and Culture of Pterapogon kauderni. John Wiley \& Sons, Ltd., Chichester, UK. Doi: 10.1002/9781119950387.

Vagelli A.A., M. Burford, and G. Bernardi. 2009. Fine scale dispersal in Banggai Cardinalfish, Pterapogon kauderni, a coral reef species lacking a pelagic larval phase. Marine Genomics, 1: 129-134. Doi: 10.1016/j.margen.2009.01.001

Zalasiewicz, J., M. Williams, A. Haywood, and M. Ellis. 2011. The Anthropocene: a new epoch of geological time. Philosophical Transactions of the Royal Society Series A, 369: 835-841. Doi: 10.1098/rsta.2010.0339.

Zoccarato. I., G. Benatti, M.L. Bianchini, M. Boccignone, A. Conti, R. Napolitano, and G.B. Palmegiano. 1994. Differences in performance, flesh composition and water output quality in relation to density and feeding levels in rainbow trout Oncorhynchus mykiss (Walbaum), farming. Aquac. Res., 25: 639-647. 